\title{
Class 2 Uveal Melanoma
}

National Cancer Institute

\section{Source}

National Cancer Institute. Class 2 Uveal Melanoma. NCI Thesaurus. Code C111021.

Gene expression profiling that classifies uveal melanomas into a high-grade group. 